F. Reprod. Fert. (1972) 28, 105-107

\title{
BACTERIUM-LIKE PARTICLES IN DELAYED IMPLANTING RAT BLASTOCYSTS
}

\author{
J. T. WU AND R. K. MEYER \\ Worcester Foundation for Experimental Biology, Shrewsbury, Massachusetts, and \\ Department of Zoology, University of Wisconsin, \\ Madison, Wisconsin, U.S.A.
}

(Received 16th Fuly 1971, accepted 12th August 1971)

Bacteria can be found in the reproductive tracts of both sexes; some of them are highly spermicidal and may be responsible for infertility (Matthews \& Buxton, 1951; Teague, Boyarsky \& Glenn, 1971). It has been reported that several viruses can infect and damage implanted mammalian embryos (Sever \& London, 1969).

In rabbits, the blastocyst is susceptible to viral and bacterial infections only when implantation has begun (Zimmermann, Gottschewski, Flamm \& Kunz, 1963). By contrast mengo-encephalitis virus is capable of infecting, and blocking the further development of, two-cell mouse eggs and morulae in vitro (Gwatkin, 1963, 1967). This communication describes the bacterium-like particles in four rat blastocysts during delayed implantation.

Five 30-day-old female rats of Holtzman strain were induced to ovulate with PMSG (Gonadogen, Upjohn Co.) followed by HCG (International Hormones, Inc.), and were mated with fertile males (Wu \& Meyer, 1966). Implantation of blastocysts was prevented by ovariectomy of the rat on Day 3 of pregnancy (Day 1 = vaginal plug), followed by daily progesterone treatment ( $\mathrm{Wu} \&$ Meyer, 1966). These rats were injected with $1 \mu \mathrm{g}$ oestrone (to induce implantation) on Day 8 at 09.00 hours, and killed $30 \mathrm{hr}$ later. The uteri were trimmed free of excess tissues and flushed with T.C. Medium 199 (Microbiological Associates, Inc.). The washings were examined for blastocysts with a dissecting microscope $(\times 40$ to 80$)$. Ten zona-free blastocysts were recovered from two rats (there were none in the remaining three). These blastocysts were fixed in cold $\mathrm{OsO}_{4}(3 \%$ in Zetterqvist's salt solution; Pease, 1964) for $60 \mathrm{~min}$, suspended in agar blocks, dehydrated and finally embedded in Epon-Araldite mixture (Mollenhauer, 1964). Six of the blastocysts were sectioned individually with a Porter-Blum microtome (MT-2), using a diamond knife. The sections were stained with uranyl acetate and lead citrate, and examined with a Hitachi electron microscope (HS-7S).

All six blastocysts sectioned showed ultrastructural characteristics of typical oestrogen stimulation, i.e. accumulation of glycogen and formation of many inclusion bodies ( $\mathrm{Wu}, 1969$ ). In addition, four of the six blastocysts showed many peculiar spherical particles in the intercellular space (Pl. 1, Figs. 1 to 3) and in the blastocoele near the trophoblast.

Although fine structural details were not well preserved in these particles 
(Pl. 1, Figs. 2 and 3), three components were discernible: (1) a dense outer wall; (2) a moderately dense inner layer; and (3) some material in the centre core area, which in several cases appeared to have fibrous structures extending radially into the two outer components (P1. 1, Fig. 3, particle C). The largest particles ranged from 0.8 to $1.2 \mu \mathrm{m}$ in diameter, while the outer wall and inner layer were both of approximately 50 to $80 \mathrm{~nm}$ thick.

In a few instances, the particles exhibited unique configurations, as shown in Pl. 1, Figs. 2 and 3. In particle A of both figures, a discontinuity appeared in the outer wall and was filled with a mass of material (arrows), suggesting that the material was either being taken in or being released into the intercellular space. Particles A and B in Pl. 1, Fig. 3 suggest that these structures were in the process of binary fission, fusion or budding.

The nature of these particles is not clear. However, their sizes and general appearance seem to suggest that they may be related to spherical bacteria, bacterial cysts or spores (Robinow, 1960; Socolofsky \& Wyss, 1961; Stanier, Doudoroff \& Adelberg, 1961). Bacteria of both rod and coccus varieties have been found in the uteri of 12 to $35 \%$ of mature and immature mice, depending on the strain (Tregier \& Homburger, 1961). Since bacteria have a thick cell wall and lack a nuclear envelope, they usually require different fixation techniques from those for the eukaryocytes; it is, therefore, not surprising that their fine structures were not adequately preserved in the present study.

It is possible that the zona pellucida may normally protect the preimplantation embryos from viral and bacterial infections by preventing their physical contact. Once the zona is broken or shed, regardless of whether implantation is imminent, in progress or prevented by ovariectomy, the trophoblast comes into contact with these micro-organisms and infection becomes possible. This, of course, is in contrast to the observation of Gwatkin (1967) that mengovirus can infect zona-encased mouse eggs even more readily than the zona-free ones. It remains to be shown, especially ultrastructurally, whether the immotile virus can penetrate through the zona pellucida, as opposed to merely being adsorbed to, or being trapped by, the depressions and shallow channels in the zona pellucida.

This study was supported in part by a grant from the Ford Foundation to R. K. Meyer and by a grant from NIH, U.S.P.H.S. (HD 03003) to M. C. Chang.

\section{EXPLANATION OF PLATE 1}

Fig. 1. A section of delayed rat blastocyst $30 \mathrm{hr}$ after oestrogen injection. Many spherical particles $(\mathrm{P})$ are present exclusively in the intercellular space. The trophoblast cells are characterized by dense cytoplasm, resulting from abundant organelles and glycogen accumulation, while the cells of the inner cell mass (I) have lighter cytoplasm. $\times 5400$. FIGs. 2 and 3. Sections of blastocysts at a higher magnification, showing details and some unusual configurations (particles A, B and $G$ ) of the spherical particles. See text for explanations. a, outer wall; b, inner layer; c, centre core; G, glycogen granules in a trophoblast cell. Fig. 2, × 17,500; Fig. 3, × 16,000. 

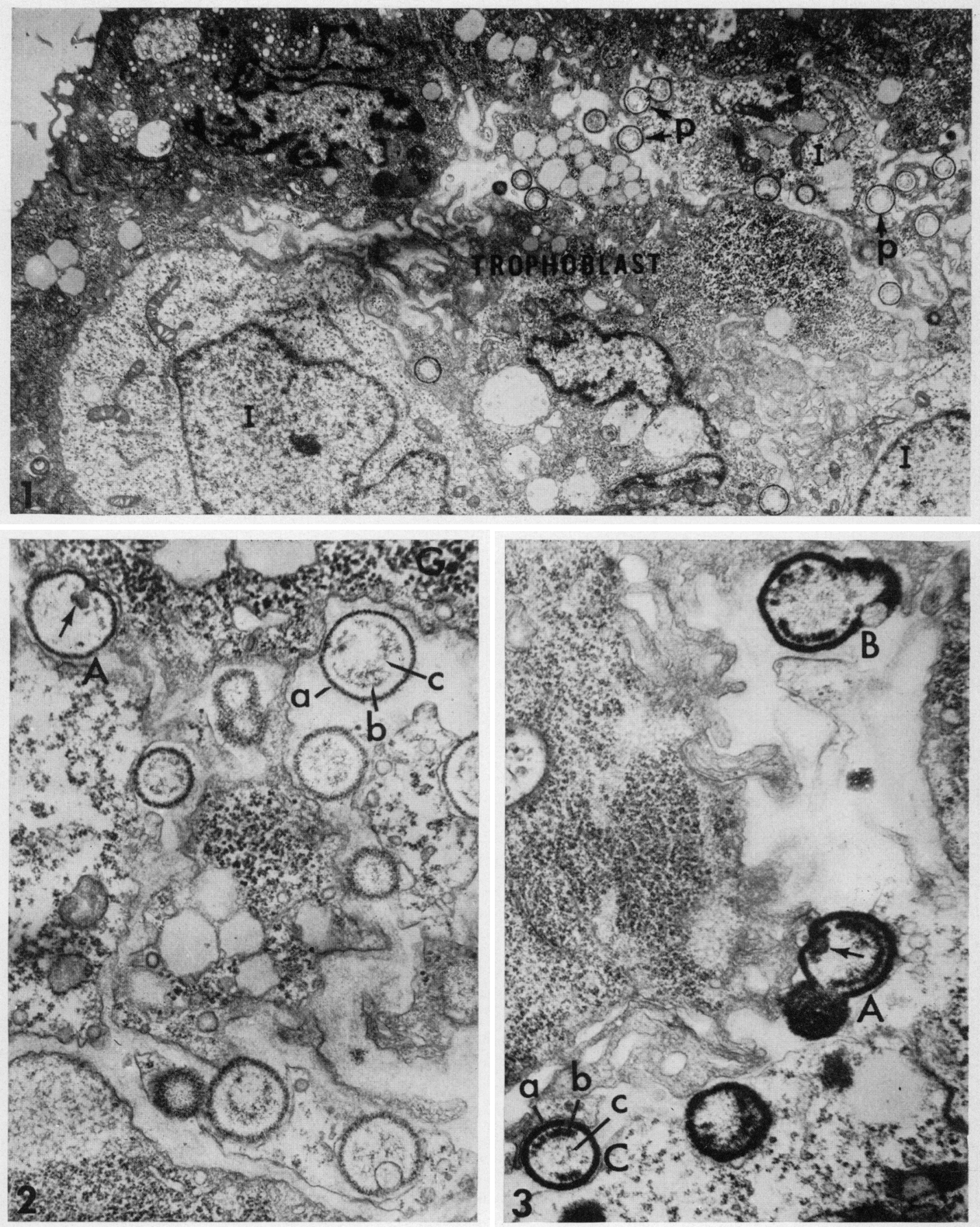

(Facing p. 106) 


\section{REFERENCES}

Gwatkin, R. B. L. (1963) Effect of viruses on early mammalian development. I. Action of Mengo encephalitis virus on mouse ova in vitro. Proc. natn. Acad. Sci. U.S.A. 50, 576.

Gwatkin, R. B. L. (1967) Passage of Mengovirus through the zona pellucida of the mouse morula. F. Reprod. Fert. 13, 577.

Matthews, C. S. \& Buxton, C. L. (1951) Bacteriology of the cervix in cases of infertility. Fert. Steril. 2, 45.

Mollenhauer, H. H. (1964) Plastic embedding mixtures for use in electron microscopy. Stain Technol. $39,114$.

Pease, D. C. (1964) Histological techniques for electron microscopy, 2nd edn. Academic Press, New York.

RoBinow, G. F. (1960) Morphology of bacterial spores, their development and germination. In: The Bacteria, Vol. 1, Structure. Eds. I. C. Gunsalus and R. Y. Stanier. Academic Press, New York.

SeVer, J. L. \& London, W. T. (1969) Viruses and embryos. Teratology, 2, 39.

Socolofsky, M. D. \& Wyss, O. (1961) Cyst of Azotobacter. 7. Bact. 81, 946.

Stanier, R. Y., Doudoroff, M. \& Adelberg, E. A. (1961) The microbial world. Prentice-Hall, Englewood Cliffs, New Jersey.

Teague, N. S., Boyarskx, S. \& Glenn, J. F. (1971) Interference of human spermatozoa motility by Eschericha coli. Fert. Steril. 22, 281.

Tregier, A. \& Homburger, F. (1961) Bacterial flora of the mouse uterus. Proc. Soc. exp. Biol. Med. 108, 152.

Wu, J. T. (1969) Effect of ovarian steroids and $x$-ray irradiation on preimplantation blastocysts of the rat. Ph.D. thesis, University of Wisconsin, Madison. Wisconsin.

WU, J. T. \& MEYER, R. K. (1966) Delayed implantation in gonadotropin-treated immature rats. Proc. Soc. exp. Biol. Med. 123, 88.

Znmmerman, W., Gottschewski, G. H. M., Flamm, H. \& Kunz, C. (1963) Experimentelle untersuchungen über die Aufnahme von Eiweiss, Viren und Bakterien während der Embryogenese des Kaninchens. Devl Biol. 6, 233. 